\title{
Determinants of financial stability: an empirical study of commercial banks listed in Muscat Security Market
}

\author{
Faris Nasif Alshubiri \\ Dhofar University \\ College of Commerce and Business Administration, Sultanate of Oman
}

\section{Keywords}

Financial Banking Stability, Commercial Banks, Sultanate of Oman

\begin{abstract}
This study aims to explain the factors that have an effect on financial banking stability measured by Z- score as determinants of all six banks listed in MSM of Oman over the period 2008 to 2014. The four factors used are bank specific factor measured by income diversity and size of bank, banking sector measured by concentration in market and P/E ratio, macroeconomics factor measured by inflation and gross demotic product growth and external governance measured by size of government and regulation. This study used OLS regression analysis and shows there is a significant impact of income diversity variable and P/E ratio. Multiple regressions shows only specific bank and banking sector factors are significant. Finally, all independent factors are statistical impact on financial banking stability. The researcher recommends is to build system for detection of risks in the banking sector to maintain financial banking stability and mitigate the power crises.
\end{abstract}

Corresponding author: Faris Nasif Alshubiri

Email address for corresponding author: fa_shub@yahoo.com

First submission received: 24th February 2017

Revised submission received: 12th April 2017

Accepted: 10th May 2017

\section{Introduction}

A financial stability of any country is an important factor in going to the world through increased international business, where the strength of completion in the market has led to interesting governments to think the conclusion of international trade agreements. These agreements will be increase economic activity, but this activity will depend on how the stability of the financial system of the country thus facilitating the process of contracting in commercial contracts(Uhde and Heimeshoff, 2009).The financial stability comes through relative stability of the indicators of monetary and fiscal policy,so this issue reflects the growth in the country economy, but to go to the world punctuated by the risks of the country must work to be avoided or mitigated with the need to understand the mechanism of the economic cycle and the nature of the economy if it is open or closed economy or where it significantly contributes to financial stability and access to global markets(Kato and Hagendorff,2010). The stability of prices on all commercial and financial activities contribute to financial stability in the country in all process and is working to increase employment and sustainable development in the country, where the countries are working to adjust and balance job supply and demand for cash in the market and the most important tool of monetary policy is to determine the credit limits to deposits to maintain depositors' money and the same time to be a flexible policy to stimulate the economy (Gan,2004).

The Financial stability index is a sensitive indicator in definition because of that a lot of economic, financial and behavioral factors interact with each other in building the financial system and defines financial stability as all activities and economic sectors of financial and operating flexibly to absorb financial crises easily and losses low. The factors of financial stability work to reduce the 
power of the financial crises that can occur in the countries by giving early warning system for financial crises and vice versa that financial instability may adversely affect the economy and financial markets and works on the demolition of the financial system in the country and affect the safety scale and reputation in the long run (Stock and Watson, 2002).

The occurrence of the modern global financial crises in 2007 led to the interest of many emerging and developing countries need to adopt models for early warning of the financial crisis in addition to the attempt of these countries to seek mechanisms, studies and experiments can be used to absorb potential losses. This problem of this study is crystallized in determining factors have effect on financial stability in banking system of Sultanate of Oman, and especially after fluctuations in global oil prices over the past seven years .Many GCC countries depend mainly on oil revenues, also the sultanate of Oman as a one of GCC countries depend on oil revenues as the main source of income for the country to move and build economy and infrastructure construction, which the government called the study of the mechanics to dealing with these changes in the environment and give alternatives about any risks faced in the future .

The importance of this study lies in identifying factors that have effect on the financial banking stability and its impact on the sustainable development of the economy of the country to build a stable bank financial system that supports the country income by increasing credit and stimulate domestic and foreign investment, especially that Oman is a gain of $45 \%$ of the population of the country are foreign people. Hence, this percentage which is high should be optimally exploited in building resources and infrastructure, by sharing the expertise and skills to participate and build infrastructure of country and take a benefit from the experiences of these countries that make up the foreign proportion of the population. Also, the transparency of the work instructions of the Central Bank of Oman contributes to building a strong and stable financial sector in all the time stages as the work safely and accurately in banking operations leads to the stability of the Central Bank of the laws which contribute to building international agreements and shares trade between nations working to build financial sector Omani growth. Thus, the aim of this study is determine the factors through the classification of financial banking stability index into four factors consists of bank specific factor, banking sector factor, macroeconomics factor and external governance. The dependent variable is financial banking stability measured by Z- score applied in six commercial banks listed in Muscat Security Market (MSM) over the period 2008- 2014.

This study contribute to building a theoretical framework illustration on the concept of banking financial stability in the Sultanate of Oman with a quantitative method to determine the factors affecting the financial banking stability by relying on monetary and fiscal policy and the extent of their response to environmental changes and build a bank health system, especially in light of the increasing competition on the local and international levels, which banks summoned to work hard to maintain the survival and thinking about how to increase the bank activities but the degree of risk is low and this will not be achieved without that there will be stability in the financial system of the country in general and the banking system in particular, to work on the construction of a gradual growth in performance and profitability. This study organized in five sections, after introduction, literature review, methodology, empirical results and discussion and finally, present conclusion.

\section{Literature Review}

In the recent years, the stability and banking of financial system become very critical point in build the economic system and determine the international trade of any country .In the study of Boot and Thakor (2000)indicated that the large banks working on keep their reputation and competitive position in the market and therefore operate on credit with special category of customers which maximizes the market value and increase the return on investment and that the way banks operate on the banking and financial stability. The study of Langrin (2002) suggested the existence of 
an early warning system which monitors of the changes that can occur at the level of macro and micro economic indicators and is working to determine the stability of the banking indicators.

On other hand Fell and Schinasi (2005) found that financial stability must be in harmony with the nature of the economy and that it is determined by the extent of integration and interaction with all economic activities in the market, while study of Van den End (2006) indicated that the balance sheet information is important to determine the financial analysis indicators and comparisons between banks to determine the banks' position in the market and the extent of stability. Financial stability achieves efficiency in the financial system and to the contrary, the lack of banking stability achieves risk in operations, which increases the complexity of the organizational work and threatens the survival of the market (Cetorelli et al. 2007).In the study of Berger et al. (2009) explained that the concentration of power in the market and the competition of the key factors in determining the stability of the banking to operate synchronously.

Albulescu (2010)indicated that overall economic variables of the key factors in achieving financial stability and increase the survival of banks in the market. Islamic banks have proved that the low sensitivity of its financial statements in the case of non-financial stability due to the nature of banking operations, which reduce the financial risk (Ariss, 2010) Anginer et al. (2012) found that there is a positive relationship between the index and regular competition and stability and that this result depends on the banks' ability to recruit assets optimally. Financial stability is determined by policy-making for the functioning of the financial system, so that the work reflects positively on prices in the market (Cukierman, 2013). While in the study of Gali (2014) found that financial stability depends on the nature of the existing demand in the market and on the size of the money supply so that reacts demand and supply in the market is pricing in light of monetary policy in the country and this reflects the extent of financial stability. The previous studies can be classified by studying the economic and financial indicator to see the effect of the relationship with the banking or financial stability. The current study was characterized as one of the studies, which brought together more than one variable at the domestic level of the bank sector and the economic and political indicator for this study can be detected by the most influential factor on the financial banking stability.

\section{Methodology of Study}

The quantitative equation used to analysis the determinants of financial banking stability on commercial banks of Sultanate of Oman.

\subsection{Data Population \& Variables Selection}

This study used all population of six banking sector listed in Muscat Security Market (MSM) over the period 2008 -2014. This period was used in the study due to lack of published data availability in MSM before this period, so this point is the limitation of this study. The impendent variables include four factors as follows: bank specific variables, banking sector variables, macroeconomics variables and external governance (economic freedom) variables. The data collected by annual companies 'guide form the period 2008 to 2015 listed in MSMalso, annual report of economic freedom of the world (2015)and statistical bulletin from 2008 to2014 from Central Bank of Oman. The independent variables that are clarify in this study are listed as follows:

Bank Specific Factor (BS): This measure refers to the internal factors of the bank and its sensitivity to the financial stability of the banking where the internal changes are reflected on the rules of procedure of the bank then this impact extends to financial banking system as a whole at the country level and determine the extent of the financial banking stability and measured by: Income Diversity (ID) = 1 - $\mid$ (Net interest income - Other operating income) / Total operating income $\mid$ and Size of Bank (SB) $=$ Logarithm of the total assets of a bank

Banking Sector Factor (BSE): This measure indicates the sensitivity of the entire banking sector to banking stability, and these results from the interaction of internal and external factors together to 
influence the level of competition in the market and how to attract customers to get a greater return to the banking financial stability and measured by:

Concentration in Market (CIM) measured by Herfindhal-Hirschman Index and P/E Ratio

Macroeconomic Factor (ME): This measure refers to economic factors at the country level and the extent of their impact in the economic cycle and financial systems, and that light is determined by the flexibility of policies and procedures in the country and that control of fiscal and monetary policy, which is reflected on the financial banking stability and measured by: Inflation (IN)= Year-on-year change of the CPI index (Percent) and GDP Growth (GDPG).

External Governance (Economic Freedom) (EG): This measure refers to the scale of economic freedom factors against which determines the proportion of foreign trade and the extent of its contribution to the gross domestic product and its reflection on the financial banking stability and measured by Size of Government (SG) and Regulation (RE). But the dependent variable is financial banking stability (FBS) measured insolvency risk measured by Z-score: [ROA +(E/TA)] / SD of ROA.

\subsection{Models of Study}

Many studies explained and focused on financial banking stability such as Gan, (2004) and Fell and Schinasi (2005). This study formulates four equations are formulized to exploring the determinants of financial banking stability as presented below:

Main Model:

Financial Banking Stability $\left(\mathrm{FBS}_{\mathrm{it}}\right)=\alpha_{0}+\beta_{1} \mathrm{BS}_{\mathrm{it}}+\beta_{2} \mathrm{BSE}+\beta_{3} \mathrm{ME}_{\mathrm{it}}+\beta_{4} \mathrm{EG}_{\mathrm{it}}+\epsilon_{\mathrm{it}}(\mathrm{Eq} \cdot 1)$

There are sub models from the main model:

Financial Banking Stability $\left(\mathrm{FBS}_{\mathrm{it}}\right)=\alpha_{0}+\beta_{1} \mathrm{ID}_{\mathrm{it}}+\beta_{2} \mathrm{SB}+\epsilon_{\mathrm{it}}(\mathrm{Eq} .2)$

Financial Banking Stability $\left(\mathrm{FBS}_{\mathrm{it}}\right)=\alpha_{0}+\beta_{1} \mathrm{CIM}_{\mathrm{it}}+\beta_{2} \mathrm{PER}+\epsilon_{\mathrm{it}}$ (Eq.3)

Financial Banking Stability $\left(\mathrm{FBS}_{\mathrm{it}}\right)=\alpha_{0}+\beta_{1} \mathrm{IN}_{\mathrm{it}}+\beta_{2} \mathrm{GDPG}+€_{\mathrm{it}}$ (Eq.4)

Financial Banking Stability $\left(\mathrm{FBS}_{\mathrm{it}}\right)=\alpha_{0}+\beta_{1} \mathrm{SG}_{\mathrm{it}}+\beta_{2} \mathrm{RE}+€_{\mathrm{it}}$ (Eq.5)

\section{Empirical Results and Discussion}

\subsection{Analysis of OLS Regression of Each Independent Variable}

Table 1 shows the results of OLS regression analysis of the bank specific factor measured by income diversity and size of bank and found there is a significant impact of income diversity on financial banking stability at $1 \%$ significant level $(\mathrm{sig}=0.000)$ at $\mathrm{t}$ - value $=-3.918$, with correlation $52.7 \%$.

The results can be explained that the bank size is not affected, mainly in determining the financial banking stability in the Sultanate of Oman, where there could be small banks in size but are working efficiently and effectively achieved through which a relatively financial banking stability and reflected positively on their profits, while the income diversity in the market indicators that are considered high sensitivity in determining financial stability as the Omani banks has recently focused on achieving growth in the credit portfolio and improve the quality of service to keep their customers and to achieve safety for depositors with government support contributes to the sustainable development. This study consistent with Boot and Thakor (2000) related to size of banks.

Table 1. OLS Regression Analysis of Bank Specific Factor on Financial Banking Stability

\begin{tabular}{lllllll}
\hline Variable & $\mathbf{R}$ & $\mathbf{R}^{2}$ & T- Value & Sig & \multicolumn{3}{l}{$\begin{array}{l}\text { Un standardized } \\
\text { Coefficient }\end{array}$} \\
\hline Bank Specific Factor & & & & & \multicolumn{3}{l}{ St-Error } & B \\
\hline Income Diversity (ID) & 0.527 & 0.277 & -3.918 & $0.000^{* \star *}$ & 1.619 & -6.343 \\
Size of Bank (SB) & 0.246 & 0.061 & -1.606 & 0.116 & 1.688 & -2.711 \\
\hline
\end{tabular}

Source: OLS regression analysis test from SPSS program. 
Table 2 shows the results of OLS regression analysis of the banking sector factor measured by concentration in market and $\mathrm{P} / \mathrm{E}$ ratio and found there is a significant impact of $\mathrm{P} / \mathrm{E}$ ratio on financial banking stability at $5 \%$ significant level $(\mathrm{sig}=0.018)$ at $\mathrm{t}$ - value $=-2.471$, with correlation $36.4 \%$.The results can be explained that the banking sector is working in an integrated and coherent with each other within the monetary policy determined by the government through the central bank and reflected positively on $\mathrm{P} / \mathrm{E}$ ratio contributed so effectively to achieve financial stability. This study consistent with Kato and Hagendorff (2010) related to nature of banking operation, that's mean related to market and study of Berger, et.al (2009) about the concentration in market

Table 2. OLS Regression Analysis of Banking Sector Factor on Financial Banking Stability

\begin{tabular}{lccccll}
\hline Variable & $\mathbf{R}$ & $\mathbf{R}^{2}$ & $\begin{array}{l}\text { T- } \\
\text { Value }\end{array}$ & Sig & \multicolumn{3}{l}{$\begin{array}{l}\text { Un standardized } \\
\text { Coefficient }\end{array}$} \\
\hline Banking Sector Factor & & & & & St-Error & $\mathbf{B}$ \\
\hline $\begin{array}{l}\text { Concentration in Market } \\
\text { (CIM) }\end{array}$ & 0.165 & 0.027 & -1.055 & 0.298 & 7.839 & -8.270 \\
P/E Ratio (PER) & 0.364 & 0.132 & -2.471 & $0.018^{* *}$ & 0.036 & $-9.00 \mathrm{E}-02$ \\
\hline
\end{tabular}

Source: OLS regression analysis test from SPSS program.

Table 3 shows the results of OLS regression of analysis the macroeconomic factor measured by inflation and GDP growth and found all variables insignificant impact of on financial banking stability. The results can be explained that the economic variables in the Sultanate of Oman does not have the sensitivity to influence the extent of the financial banking stability as with the rapid changes in the economy that the government is working to support the banking sector, so as to achieve relative stability in the banking operations. This study consistent with Langrin (2002) related to economic factor determines the financial stability.

Table 3. OLS Regression Analysis of Macroeconomic Factor on Financial Banking Stability

\begin{tabular}{lllllll}
\hline Variable & R & $\mathbf{R}^{2}$ & $\begin{array}{l}\text { T- } \\
\text { Value }\end{array}$ & Sig & \multicolumn{2}{l}{$\begin{array}{l}\text { Un standardized } \\
\text { Coefficient }\end{array}$} \\
\hline Macroeconomic Factor & & & & & St-Error & B \\
\hline Inflation (IN) & 0.079 & 0.006 & 0.498 & 0.621 & 4.327 & 2.156 \\
GDP Growth (GDPG) & 0.050 & 0.002 & -0.314 & 0.755 & 0.587 & -0.184 \\
\hline
\end{tabular}

Source: OLS regression analysis test from SPSS program.

Table 4 shows the results of OLS regression analysis of the external governance factor measured by size of government and regulation and found all variables insignificant impact of on financial banking stability. The results can be explained that the political changes related to economic freedom index is weak influence on the financial banking stability as the government is working on the management of monetary and fiscal policies in the light of the economic requirements.

Table 4. OLS Regression Analysis of External Governance Factor on Financial Banking

\begin{tabular}{lllllll}
\hline Variable & $\mathbf{R}$ & $\mathbf{R}^{2}$ & T-Value & Sig & \multicolumn{3}{l}{$\begin{array}{l}\text { Un standardized } \\
\text { Coefficient }\end{array}$} \\
\hline $\begin{array}{l}\text { External Governance } \\
\text { Factor (Economic } \\
\text { Freedom) }\end{array}$ & & & & & St-Error & $\mathbf{B}$ \\
\hline Size of Government (SG) & 0.203 & 0.041 & -1.312 & 0.197 & 1.889 & -2.478 \\
Regulation (RE) & 0.123 & 0.015 & -0.782 & 0.439 & 2.426 & -1.897 \\
\hline
\end{tabular}

Source: OLS regression analysis test from SPSS program.

\subsection{Analysis of Multiple Regressions of all Independent Variable}

Table 5 shows the results of OLS multiple regression analysis of each four factors of bank specific, bank sector, macroeconomic and external governance (economic freedom) and found there 
is a significant impact of bank specific and bank sector on financial banking stability at $1 \%$ and $10 \%$ significant level respectively at $(\mathrm{sig}=0.002$ and 0.052$)$ at $\mathrm{F}$ - value $=7.687$ and 3.184 , with correlation $53.2 \%$ and $37.5 \%$.and $\mathrm{R}^{2}=28.3 \%$ and $14 \%$.

The results can be explained that the internal factors in the banks' own engagement and influence in financial banking stability of country, suggesting the central bank interest in the development of policies and control procedures court on the performance of banks, allowing banks to a degree of financial stability

Table 5. OLS Multiple Regression Analysis of Each Independent Variables on FBS

\begin{tabular}{lllll}
\hline Variables & $\mathbf{R}$ & $\mathbf{R}^{\mathbf{2}}$ & $\mathbf{F}$ & Sig \\
& & & Value & \\
\hline Bank Specific Factor & 0.532 & 0.283 & 7.687 & $0.002^{* * *}$ \\
Bank Sector Factor & 0.375 & 0.140 & 3.184 & $0.052^{*}$ \\
Macroeconomic Factor & 0.107 & 0.011 & 0.224 & 0.800 \\
External Governance (Economic Freedom) & 0.228 & 0.052 & 1.074 & 0.351 \\
Factor & & & & \\
\hline
\end{tabular}

Source: Multiple regression analysis test from SPSS program.

Table 6 shows the results of OLS multiple regression analysis of all four factors of bank specific, bank sector, macroeconomic and external governance (economic freedom) and found there is a significant impact of all independent factors on financial banking stability at $10 \%$ significant level at $\operatorname{sig}=0.057$ at $\mathrm{F}$ - value $=2.162$, with correlation $58.6 \%$ and $\mathrm{R}^{2}=34.4 \%$. The results can be explained that all the independent variables have an impact on banking stability, suggesting the banking sector in Oman follow balanced strategy works in the bank credit granted.

Table 6. OLS Multiple Regression Analysis of All Independent Variables on FBS

\begin{tabular}{lllll}
\hline Variables & $\mathbf{R}$ & $\mathbf{R}^{2}$ & F- Value & Sig \\
\hline All Factors of Financial Banking Stability & 0.586 & 0.344 & 2.162 & $0.057^{*}$ \\
\hline
\end{tabular}

Source: Multiple regression analysis test from SPSS program.

\subsection{Analysis of Pearson Correlations Matrix between all Variables}

Table 7 shows the results of Pearson correlations matrix between all variables. The results found there is a significant relationship between income diversity, concentration in market, regulation and size of bank at $1 \%, 10 \%$ and 5\% significant level, size of government, financial banking stability and income diversity at $10 \%$, and $1 \%$ significant level, inflation, size of government, regulation and concentration in market at 1\%,5\% significant level, financial banking stability and $\mathrm{P} /$ Eratio at $5 \%$ significant level. Finally, there is a significant relationship between regulation and inflation at $1 \%, 5$ significant level.

Table 7. Pearson Correlations Matrix between all Variables

\begin{tabular}{|c|c|c|c|c|c|c|c|c|c|c|}
\hline & & SB & ID & CIM & PER & INF & GDPG & SG & $\mathrm{RE}$ & FBS \\
\hline \multirow{2}{*}{ SB } & PC & 1 & & & & & & & & \\
\hline & Sign2-T & & & & & & & & & \\
\hline \multirow[t]{2}{*}{ ID } & $\mathrm{PC}$ & 0.581 & 1 & & & & & & & \\
\hline & Sign2-T & 0.000 & & & & & & & & \\
\hline \multirow[t]{2}{*}{ CIM } & PC & 0.290 & 0.206 & 1 & & & & & & \\
\hline & Sign2-T & 0.062 & 0.191 & & & & . & & & \\
\hline \multirow[t]{2}{*}{ PER } & PC & 0.000 & 0.241 & 0.212 & 1 & & & & & \\
\hline & Sign2-T & 0.998 & 0.125 & 0.177 & & & & . & & \\
\hline \multirow[t]{2}{*}{ INF } & PC & -0.230 & -0.133 & -0.602 & -0.098 & 1 & & & & \\
\hline & Sign2-T & 0.143 & 0.400 & 0.000 & 0.537 & & & & . & \\
\hline \multirow[t]{2}{*}{ GDPG } & PC & 0.025 & 0.081 & 0.240 & -0.202 & 0.256 & 1 & & & \\
\hline & Sign2-T & 0.875 & 0.610 & 0.126 & 0.200 & 0.102 & & & & . \\
\hline SG & $\mathrm{PC}$ & 0.256 & 0.270 & 0.389 & 0.123 & -0.180 & 0.226 & 1 & & \\
\hline
\end{tabular}

www.jbrmr.com A Journal of the Academy of Business and Retail Management (ABRM) 
Journal of Business and Retail Management Research (JBRMR), Vol. 11 Issue 4

\begin{tabular}{ccccccccccc}
\hline \multicolumn{1}{c}{ RE } & Sign2-T & 0.102 & 0.084 & 0.011 & 0.439 & 0.254 & 0.150 & & & \\
& P C & 0.314 & 0.240 & 0.773 & 0.039 & -0.696 & 0.029 & 0.091 & 1 & \\
& Sign2-T & 0.043 & 0.125 & 0.000 & 0.806 & 0.000 & 0.857 & 0.565 & & \\
FBS & P C & -0.246 & -0.527 & -0.165 & -0.364 & 0.079 & -0.050 & -0.203 & -0.123 & 1 \\
& Sign2-T & 0.116 & 0.000 & 0.298 & 0.018 & 0.621 & 0.755 & 0.197 & 0.439 & \\
\hline
\end{tabular}

Source:* Correlation is sig at the 0.05 level and ${ }^{* *}$ Correlation is sig at the 0.01 level (2-tailed).

We note that the banking sector in Oman follow policy in Oman, which is an important step in the development of the banking business and its commitment to the implementation of the Central Bank of Oman's policy was observed continued growth in loans granted to small and medium enterprises, which contributed to the growth of banks' revenues and improve the performance of an increased risk of piracy and cybercrime of the highlights of the operational risks facing the banking industry in the world, and work to strengthen the role of Islamic banking in the payment of financial deepening and inclusion banking and finance major projects comes.

The Central Bank of Oman continued to strengthen the regulatory and supervisory standards in line with international best practices in this area. The Central Bank of Oman is conduct a selfassessment system for supervision and practices because the need to evaluate compliance with the basic principles recommended by the BASEL Committee I and II and III. It encourages banks to adjust, refine risk systems, corporate governance, internal control systems and practices of disclosure and transparency. In 2002, the promulgation of a law to combat money laundering Constitute a period (2011-2014) an important stage with the launch of Islamic banking in Oman in December 2012, as this period witnessed the taking several initiatives on the level of regulation and supervision have been established financial stability department within the Central Bank of Oman to take control of the precautionary safety overall financial system. Focus efforts on the implementation of BASEL III and control based on the risks and the financing of small and medium enterprises.

The dealing with global and regional crises flexibly is to convert its repercussions to the reservoirs of the opportunities and the modernization and development one of the main features of the performance of the Central Bank of Oman over the years. In this context, it was dealing with the global financial crisis 2008-2009 and its repercussions on the oil markets, the real economy as the most serious challenges faced by the banking system in the Sultanate of Oman due to the coverage of all countries in the world and the impact of crude oil prices. The Omani banks' strength comes through the flexibility of the central bank's actions in dealing with the banks and at the same time control the progress of work under the specific criteria

Central bank of Oman permanently follows a consultative approach to identify and adopt rules and regulations for the banking sector regulators, including the instructions of the BASEL III, which was released in November of 2013. Regarding the development of banks operating in the Sultanate of Oman in terms of capital, all of them meet the minimum imposed by the Central Bank of Oman in this regard. We note here, that the merger between commercial banks leads to the emergence of large banking entities have a high ability to finance various projects, especially those with a long-term strategy as well as the ability to compete regionally and globally and reduce operational costs. The central bank is continually trying to urge banks to follow a balanced policy in their work in terms of attracting investment and creating a suitable environment for the economy healthy and at the same time maximizing the market value of banks and profitability.

\section{Conclusion}

The financial banking stability index is play a vital role in the promotion of safety and the reputation of the banking system and increase international trade in the light of the great acceleration in the economic growth of the countries where is this indicator referring to the possibility of predicting financial crises. This study aims to explain the factors that effect on financial banking stability as determinants of banking sector in Sultanate of Oman. This study used four independent 
factors consists of bank specific factor measured by income diversity and size of bank, banking sector measured by concentration in market and P/E ratio, macroeconomics factor measured by inflation and gross demotic product growth and external governance measured by size of government and regulation. The dependent variable is financial banking stability measured by Z- score. The population consists of six commercial banks listed in Muscat Security Market (MSM) over the period 2008- 2014.

This study used OLS regression analysis and the results shows there is a significant impact of income diversity variable from specific bank factor and $\mathrm{P} / \mathrm{E}$ ratio from banking sector at $1 \%$, and $5 \%$ significant level respectively, but macroeconomic and external governance factors are insignificant in all variables. Multiple regression used and the results shows only specific bank and banking sector factors are significant at $1 \%$ and $10 \%$ significant level. Finally, the regression runs for all independent factors and the result shows there is a statistical impact of all factors on financial banking stability at $10 \%$ significant level. The Pearson results found there is a significant relationship between income diversity, concentration in market, regulation and size of bank at $1 \%, 10 \%$ and $5 \%$ significant level, size of government, financial banking stability and income diversity at $10 \%$, and $1 \%$ significant level, inflation, size of government, regulation and concentration in market at $1 \%, 5 \%$ significant level, financial banking stability and P/E ratio at 5\% significant level. Finally, there is a significant relationship between regulation and inflation at $1 \%$, 5significant level.

The researcher recommends the need to adopt a system for the detection of risks in the banking and financial system to maintain financial banking stability and mitigate the power crises. The need for the banking sector's interest in developing financial control systems to reduce operational risks and achieve a high level of quality of services provided to enter the world in the provision of banking services and to achieve the levels of classification prominent among banks to increase confidence in the mechanism of dealing in foreign trade. From future studies recommended by the researcher is the ability to search the legal and market indicators related to the financial banking stability index.

\section{References}

Albulescu C., 2010. Forecasting Romanian Financial System Stability Using a Stochastic Simulation Model. Romanian Journal of Economic Forecasting, 13 (1), pp 81-98.

Anginer D., Demirguc-Kunt A.and Zhu, M., 2012. How Does Bank Competition Affect Systemic Stability? Policy Research Working Paper No. 5981, The World Bank.

Ariss, R. T., 2010. Competitive Conditions in Islamic and Conventional Banking: A Global Perspective. Review of Financial Economics, 19(3), pp101-108.

Annual Companies Guide (2008-2015), "Muscat Security Market", Available online: https://www.msm.gov.om/ (accessed on 10 November 2014).

Annual Report of Economic Freedom of the World (2015) Free the World. Com,, Fraser Institute, Available online: http:// www.freetheworld.com (accessed on 11 January 2015).

Berger A., Klapper L. and Turk-Ariss R., 2009. Bank Competition and Financial Stability. Journal of Financial Services Research, 35, pp 99-118.

Boot A.W.A. and Thakor A., 2000. Can Relationship Lending Survive Competition? Journal of Finance, 55(2), pp679-713.

Cetorelli N., Hirtle B., Morgan D., Peristiani, S. and Santos, J., 2007. Trends in Financial Market Concentration and their Implications for Market Stability. Federal Reserve Bank of New York Economic Policy Review, March, pp 33-51.

Cukierman A., 2013. Monetary Policy and Institutions Before, During, and After the Global Financial Crisis. Journal Financial Stability, 9(3), pp 373-384.

Fell J. and SchinasiG., 2005. Assessing Financial Stability: Exploring the Boundaries of Analysis. National Institute Economic Review, 192(1), pp102-117 
Gali J., 2014. Monetary Policy and Rational Asset Price Bubbles. American Economic Review, 104(3), pp721-752.

Gan J., 2004. Banking Market Structure and Financial Stability: Evidence from the Texas Real Estate Crisis in the 1980s.Journal of Financial Economics, 73, pp567-601.

Kato P. and Hagendorff J., 2010. Distance to Default, Subordinated Debt, and Distress Indicators in the Banking Industry "Accounting and Finance, 50(4), pp 853-870.

Langrin B., 2002. An Early Warning System for the Prevention of Banking Sector Crises in Jamaica, " (Bank of Jamaica Working Paper).

Stock J. H. and Watson M. W., 2002. Forecasting Using Principal Components from a Large Number of Predictors. Journal of the American Statistical Association, 97(460), pp 1167-1179.

Statistical Bulletin (2008 -2014)."Central Bank of Oman", Available online : http://www.cbooman.org/ (accessed on 10 February 2016).

Uhde A. and Heimeshoff U., 2009. Consolidation in Banking and Financial Stability in Europe: Empirical Evidence. Journal of Banking and Finance, 33(7), pp 1299-1311.

Van den End JW., 2006. Indicator and Boundaries of Financial Stability.DNB Working Paper No. 97, March. 